\title{
SIMULTANEOUS PRECONCENTRATION OF Cu(II), Cd(II) AND Mn(II) ON SILICA-POLYETHYLENE GLYCOL AND DETERMINATION BY FLAME ATOMIC ABSORPTION SPECTROMETRY
}

\author{
Nahid Pourreza*, Roya Mirzajani, Ali Reza Kiasat and Rezvan Abdollahzadeh \\ Department of Chemistry, College of Science, Shahid Chamran University, Ahvaz, Iran
}

Recebido em 26/1/12; aceito em 14/6/12; publicado na web em 21/9/12

\begin{abstract}
A simultaneous solid phase extraction procedure for enrichment of $\mathrm{Cu}(\mathrm{II}), \mathrm{Cd}(\mathrm{II})$ and $\mathrm{Mn}$ (II) has been developed. The method is based on adsorption of $\mathrm{Cu}(\mathrm{II}), \mathrm{Cd}(\mathrm{II})$ and $\mathrm{Mn}(\mathrm{II})$ ions on polyethylene glycol-silica gel pre-conditioned with acetate buffer (pH 5.5). The adsorbed metal ions are eluted with nitric acid $\left(1 \mathrm{~mol} \mathrm{~L}^{-1}\right)$ and determined by flame atomic absorption spectrometry. The calibration graph was linear in the range of 2-140 $\mathrm{ng} \mathrm{mL}^{-1}$ for $\mathrm{Cu}(\mathrm{II}), 1-40 \mathrm{ng} \mathrm{mL}^{-1}$ for $\mathrm{Cd}(\mathrm{II})$ and 4-100 $\mathrm{ng} \mathrm{mL}^{-1}$ for $\mathrm{Mn}$ (II). The limits of detection were $0.66,0.33$ and $1.20 \mathrm{ng} \mathrm{mL}^{-1}$ for $\mathrm{Cu}(\mathrm{II}), \mathrm{Cd}(\mathrm{II})$ and $\mathrm{Mn}(\mathrm{II})$, respectively.
\end{abstract}

Keywords: $\mathrm{Cu}(\mathrm{II}) ; \mathrm{Cd}(\mathrm{II}) ; \mathrm{Mn}(\mathrm{II})$.

\section{INTRODUCTION}

High concentrations of heavy metals may have severe toxicological effects on living organisms. Large amounts of heavy metals can enter the environment from metallurgy industries, combustion of coal, and automobiles. Heavy metals can easily enter the food chain through a number of pathways, and long-term exposure in a contaminated environment can cause progressive toxic effects for living organisms. Therefore, controlling heavy metal discharges and their measurement in different samples has become a challenge for analytical chemists. ${ }^{1,2}$ The flame atomic absorption spectrometry technique is extensively employed for the quantification of metallic species because of its desirable characteristics, such as low cost, ease of operation, high analytical frequency and good selectivity. However, the direct determination of trace metals by this technique is limited because of matrix interference problems and low concentration of metals in samples. However, these problems can easily be overcome by applying separation and/or preconcentration procedures before performing the detection procedure. Different methods exist for the separation and isolation of metal ions such as liquid-liquid extraction, ${ }^{3}$ ion exchange, ${ }^{4}$ flotation, ${ }^{5}$ solid phase extraction ${ }^{6-10}$ and cloud point extraction..$^{1-13}$ The inherent limitations of the methods based upon solvent extraction are the high costs of solvents and the environmental concerns regarding their disposal. Hence, solid phase extraction methods were proposed as an alternative to overcome these drawbacks of liquid-liquid extraction. The separation, preconcentration, and determination of metal ions at trace levels has been successfully accomplished using different adsorbents such as polymeric resins modified with selective ligands.

Solid phase extraction is an attractive separation and preconcentration technique for trace metal ions with advantages such as simplicity, flexibility, and high enrichment factors. Various solid phase materials have been introduced for the preconcentration and separation of heavy metal ions at trace levels, including chemically-modified silica-gel with amino thioamidoanthraquinone, ${ }^{14}$ polyurethane foam functionalized with a-naphthol,,${ }^{15}$ cellulose functionalized with 8-hydroxyquinoline, ${ }^{16}$ zeolite, ${ }^{17}$ Amberlite XAD.4 coated with dithiocarbamates, ${ }^{18}$ carboxylic acid $(\mathrm{COOH})$ bonded to silica gel, ${ }^{19}$, naphthalene ${ }^{20}$ and PAN-naphthalene. ${ }^{21}$

In this work, a solid phase extraction procedure for preconcentration

*e-mail: npourreza@scu.ac.ir of $\mathrm{Cu}(\mathrm{II}), \mathrm{Cd}(\mathrm{II})$ and $\mathrm{Mn}(\mathrm{II})$ using silica gel-polyethylene glycol (Silica-PEG) as an adsorbent is described.

\section{EXPERIMENTAL}

\section{Instrumentation}

Analysis of the metal ions was performed by a GBC atomic absorption spectrometer model Cintra 101 (Australia) with air-acetylene flame. All instrument settings were those recommended by the manufacturer. The selected wavelengths for the determination of copper, cadmium and manganese were 324.7, 228.8 and $279.5 \mathrm{~nm}$, respectively. The lamp current was $3 \mathrm{~mA}$ for copper and cadmium, and $5 \mathrm{~mA}$ for manganese. The spectral band pass was $0.5 \mathrm{~nm}$ for copper and cadmium, and $0.2 \mathrm{~nm}$ for manganese.

A digital pH-Meter model 632, Metrohm (Switzerland) with a combined glass electrode was used for $\mathrm{pH}$ adjustments. A Teb Azma vacuum pump (Iran) was used for pumping the solutions.

\section{Reagents}

Analytical reagent-grade chemicals and doubled distilled water were used throughout. Stock solutions of $1000 \mu \mathrm{g} \mathrm{mL}^{-1}$ of $\mathrm{Cu}(\mathrm{II}), \mathrm{Cd}(\mathrm{II})$ and $\mathrm{Mn}(\mathrm{II})$ were prepared by dissolving 0.3929 $\mathrm{g}$ of $\mathrm{CuSO}_{4} .5 \mathrm{H}_{2} \mathrm{O}$ (Merck, Darmstadt, Germany), $0.2282 \mathrm{~g}$ of $3 \mathrm{CdSO}_{4} \cdot 8 \mathrm{H}_{2} \mathrm{O}$ (Merck) and $0.3076 \mathrm{~g}$ of $\mathrm{MnSO}_{4} \cdot \mathrm{H}_{2} \mathrm{O}$ (Merck) in water and diluting to $100 \mathrm{~mL}$ in a volumetric flask, respectively. The working solutions were prepared by appropriate dilution of the stock solution. An acetate buffer $\mathrm{pH} 5.5$ was prepared by adding 2 mol L-1 $\mathrm{NaOH}$ to $0.1 \mathrm{~mol} \mathrm{~L}^{-1}$ acetic acid and adjusting its $\mathrm{pH}$ to 5.5 using a $\mathrm{pH}$ meter. Phosphate buffer $\mathrm{pH} 7.0$ was prepared by adding $2 \mathrm{~mol} \mathrm{~L}-1 \mathrm{NaOH}$ to $0.1 \mathrm{~mol} \mathrm{~L}^{-1}$ phosphoric acid and adjusting its $\mathrm{pH}$ to 7.0 using a pH meter. Silica gel (Aldrich 70-270 mesh, 60 surface area $\left.>500 \mathrm{~m}^{2} / \mathrm{G}\right)$ was activated by treatment with $\mathrm{HCl}\left(5 \mathrm{~mol} \mathrm{~L}^{-1}\right)$ and dried in vacuum at $120^{\circ} \mathrm{C}$. Polyethylene glycol, PEG (Merck) was heated at $80^{\circ} \mathrm{C}$ under vacuum for $30 \mathrm{~min}$ before use to remove traces of moisture.

\section{Adsorbent preparation by immobilization of polyethylene glycol on silica gel}

The adsorbent was prepared by immobilization of polyethylene 
glycol on silica gel according to a previously reported procedure. ${ }^{22}$ $20 \mathrm{~g}$ of activated silica was placed in a dried $250 \mathrm{~mL}$ flask equipped with a magnetic stirrer under nitrogen atmosphere. Subsequently, freshly distilled $\mathrm{SOCl}_{2}(45 \mathrm{~mL})$ was added slowly to the flask through an addition funnel and the reaction mixture was stirred at room temperature. Evolution of copious amounts of $\mathrm{HCl}$ and $\mathrm{SO}_{2}$ occurred instantaneously. After stirring for $4 \mathrm{~h}$, the excess unreacted thionyl chloride was distilled off and the resulting grayish silica chloride was flame dried and stored in an airtight container before use.

PEG (10 g) was added dropwise to a well-stirred silica chloride $(20 \mathrm{~g})$ in dry $\mathrm{CH}_{2} \mathrm{Cl}_{2}(40 \mathrm{~mL})$, under a nitrogen atmosphere at room temperature. $\mathrm{HCl}$ was instantaneously evaluated. After stirring for 2 $\mathrm{h}$, the obtained silica-gel supported PEG was removed by filtration. For elimination of any additional PEG, the resultant mixture was washed several times by acetone (3-30 mL). Silica-gel supported PEG was dried in a vacuum oven overnight.

\section{Recommended procedure}

A tipped glass funnel ( $7 \mathrm{~cm}$ in length and $7 \mathrm{~mm}$ i.d) with a very fine bore was packed with $0.35 \mathrm{~g}$ of the adsorbent and used as a preconcentration column. The prepared column was conditioned by passing $5 \mathrm{~mL}$ of acetate buffer $\mathrm{pH} 5.5 .200 \mathrm{~mL}$ of the solution containing 1-140 ng mL $\mathrm{m}^{-1}$ of $\mathrm{Cu}(\mathrm{II}), 1-40 \mathrm{ng} \mathrm{mL}^{-1}$ of $\mathrm{Cd}(\mathrm{II})$ and 2-100 ng mL $\mathrm{mL}^{-1}$ of $\mathrm{Mn}$ (II) and $3 \mathrm{~mL}$ of phosphate buffer $\mathrm{pH} 7.0$, was passed through the mini column at a flow rate of $10 \mathrm{~mL} \mathrm{~min}^{-1}$. The adsorbed metal ions were eluted with $3.0 \mathrm{~mL}$ of $1.0 \mathrm{~mol} \mathrm{~L}^{-1}$ of nitric acid. The metal content of the eluent was determined by FAAS and percent recoveries were calculated from the amount initially present and amount eluted from the column. A blank solution was also run under the same analytical conditions without adding any $\mathrm{Cu}$ (II), $\mathrm{Cd}(\mathrm{II})$ and $\mathrm{Mn}(\mathrm{II})$.

\section{Sample preparations}

The surface water samples were collected after rain in the local area, acidified, boiled, filtered and kept in a refrigerator before use. An aliquot of water samples was then treated under the recommended procedure. $0.2 \mathrm{~g}$ of sugar sample was dissolved in water, phosphate buffer was added and the recommended procedure was applied.

\section{RESULTS AND DISCUSSION}

We recently reported the use of Silica-PEG for preconcentration and determination of $\mathrm{Co}(\mathrm{II})$ and $\mathrm{Ni}(\mathrm{II}) .{ }^{23}$ The analytes are probably adsorbed through interaction with $\mathrm{OH}$ groups of the PEG and it seems that this polymeric compound could form complexes with cations much like crown ether. Our preliminary investigations showed that if Silica-PEG adsorbent is conditioned with acetate buffer $\mathrm{pH} 5.5$ in the column, it can also be used for simultaneous preconcentration of $\mathrm{Cu}(\mathrm{II}), \mathrm{Cd}(\mathrm{II})$ and $\mathrm{Mn}$ (II) prior to their determination by flame atomic absorption spectrometry. It should be mentioned that the recoveries were around $10 \%$ for these metal ions without pretreatment. Therefore, different parameters were optimized in order to apply this adsorbent for simultaneous preconcentration and sensitive determination of $\mathrm{Cu}(\mathrm{II}), \mathrm{Cd}(\mathrm{II})$ and $\mathrm{Mn}$ (II).

\section{Effect of pH}

It was found that if Silica-PEG adsorbent is conditioned with acetate buffer it can be used for simultaneous preconcentration of $\mathrm{Cu}(\mathrm{II}), \mathrm{Cd}(\mathrm{II})$ and $\mathrm{Mn}$ (II) while the untreated adsorbent has very low tendency towards these ions. The pHPZA of the adsorbent which corresponds to the $\mathrm{pH}$ value of the liquid surrounding oxide particles, when the sum of surface positive charges balances the sum of surface negative charges ${ }^{24}$, was determined by the Noah and Schwarz method $^{25}$ and found to be 2.2. ${ }^{23}$ This means that the surface of the adsorbent is acidic and if the $\mathrm{pH}$ of the solution is higher than $\mathrm{pHPZC}$, the negative charge on the surface provides electrostatic interactions that are favorable for adsorbing cationic species. Therefore, first the $\mathrm{pH}$ for the conditioning of adsorbent was investigated in order to make the adsorbent less acidic and acetate buffers with $\mathrm{pH}$ values of 4.50 , $5.00,5.50$ and 5.75 were used to pass through the column filled with the adsorbent before passing the sample solution. It was observed that $5 \mathrm{~mL}$ of acetate buffer $\mathrm{pH} 5.5$ was adequate for pre-conditioning of the column for quantitative retention of $\mathrm{Cu}$ (II), $\mathrm{Cd}$ (II) and $\mathrm{Mn}$ (II) and, by increasing the $\mathrm{pH}$ for the conditioning of the adsorbent, the recoveries were decreased again.

The effect of $\mathrm{pH}$ of the sample solution was also studied in the range of 5-8 by adjusting the $\mathrm{pH}$ of the solution with $\mathrm{HCl}$ or $\mathrm{NaOH}$ $\left(0.1 \mathrm{~mol} \mathrm{~L}^{-1}\right)$ using a $\mathrm{pH}$ meter. The results shown in Figure 1 indicate that highest recoveries are obtained for all metal ions at $\mathrm{pH} 7$. Therefore $\mathrm{pH} 7$ was selected as the optimum value and $3 \mathrm{~mL}$ of phosphate buffer $\mathrm{pH} 7$ was added to the solutions to maintain this value.

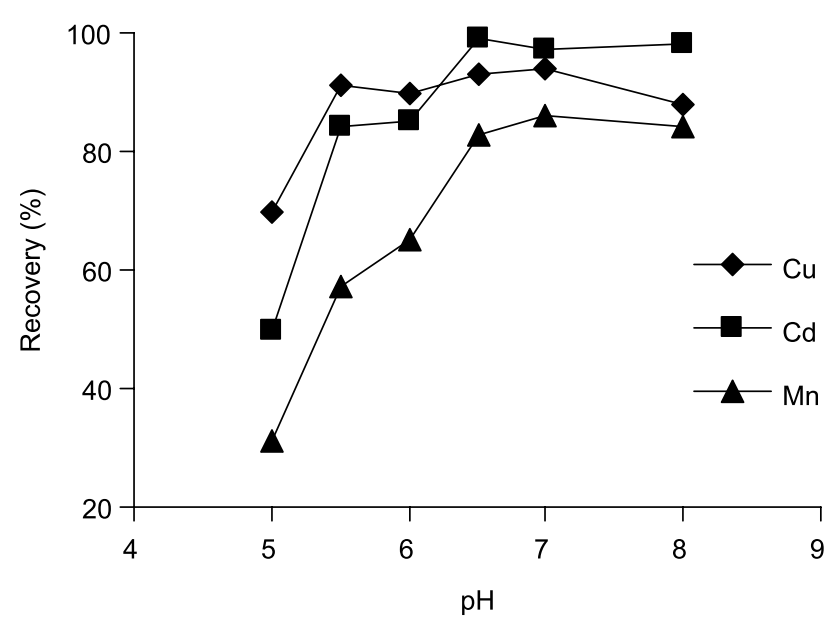

Figure 1. Effect of $\mathrm{pH}$ on the recovery of $100 \mathrm{ng} \mathrm{mL}^{-1}$ of $\mathrm{Cu}(\mathrm{II})$, and $\mathrm{Mn}(\mathrm{II})$ and $50 \mathrm{ng} \mathrm{mL}^{-1}$ of Cd(II). Each number is the average of 3 replicate measurements

\section{Effect of eluent type and eluent concentration}

Different acid solutions such as sulfuric, nitric and hydrochloric were investigated for the elution of adsorbed metal ions from the column. The highest recoveries were obtained when nitric acid solution was used as an eluent. Thus, the effect of nitric acid concentration was evaluated. The results given in Figure 2 show that the highest recoveries are achieved for desorbed metal ions when nitric acid concentration was $1.0 \mathrm{~mol} \mathrm{~L}^{-1}$. Therefore, $3 \mathrm{~mL}$ of nitric acid solution (1.0 mol L-1) was selected for the elution of $\mathrm{Cu}$ (II), $\mathrm{Cd}(\mathrm{II})$ and $\mathrm{Mn}$ (II) ions from the column. $2 \mathrm{~mL}$ was not adequate for determination of three metal ions whereas $4 \mathrm{~mL}$ would decrease the preconcentration factor.

\section{Effect of sample flow rates}

One of the parameters affecting the recovery and preconcentration time is sample flow rate. At fast flow rates there is insufficient time for equilibration between the analytes and the adsorbent while at slow flow rates, the analysis time is increased. Therefore, the effect of the sample flow rate on the adsorption of the metal ions was investigated. This study was carried out by pumping $200 \mathrm{~mL}$ of the solution containing $100 \mathrm{ng} \mathrm{mL}^{-1} \mathrm{Cu}$ (II) and $\mathrm{Mn}(\mathrm{II})$ and $50 \mathrm{ng} \mathrm{mL}^{-1}$ at different flow 


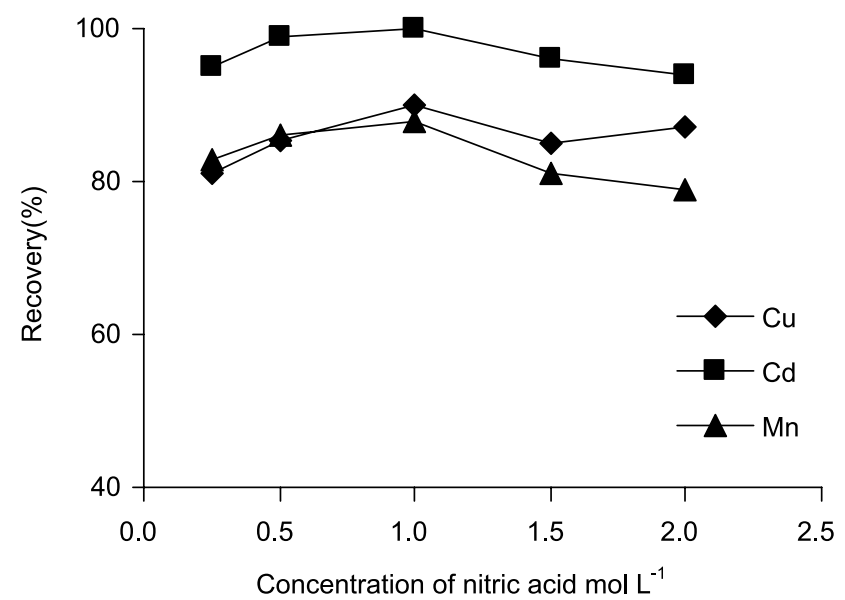

Figure 2. Effect of nitric acid concentration as the eluent on the recovery $100 \mathrm{ng} \mathrm{mL}^{-1}$ of $\mathrm{Cu}(\mathrm{II})$, and $\mathrm{Mn}(\mathrm{II})$ and $50 \mathrm{ng} \mathrm{mL}^{-1} \mathrm{Cd}(\mathrm{II})$. Each number is the average of 3 replicate measurements

rates. The results indicated that all the analyte ions were quantitatively retained and recovered in the range of $2-10 \mathrm{~mL} \mathrm{~min}^{-1}$. In posterior experiments, the flow rate was kept constant at $10 \mathrm{~mL} \mathrm{~min}^{-1}$ in order to increase the sample throughput.

\section{Effect of adsorbent amount and reusability}

Several experiments were carried out for the selection of the amount of adsorbent. The results in Figure 3 show that quantitative recoveries were obtained for all the analytes when an adsorbent amount of $0.35-0.40 \mathrm{~g}$ was used. Thus, $0.35 \mathrm{~g}$ was selected as optimum for further work.

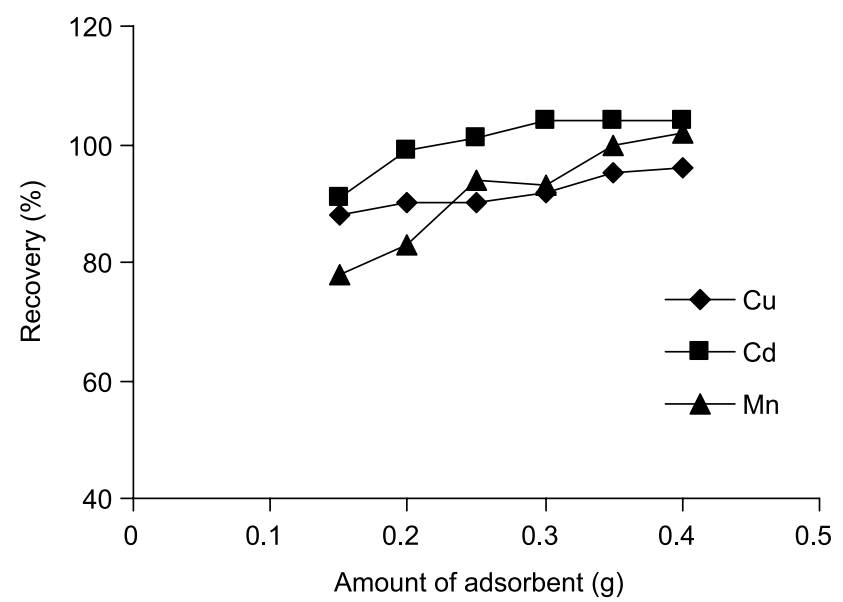

Figure 3. Effect of amount of adsorbent on the recovery of $100 \mathrm{ng} \mathrm{mL^{-1 } \text { of }}$

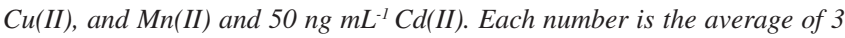
replicate measurements

The regeneration of the column was investigated to determine the reusability of the adsorbent. The column filled with $0.35 \mathrm{~g}$ of solid adsorbent was reused at optimum experimental conditions for the separation and preconcentration of $\mathrm{Cu}(\mathrm{II}), \mathrm{Cd}(\mathrm{II})$ and $\mathrm{Mn}$ (II) ions from aqueous samples. Each column was washed with water after each elution and the general procedure was applied again. The results depicted in Figure 4 indicated that each column can be used six times without serious loss in the recoveries for all metal ions. Moreover, the used adsorbents can be collected and recycled by a simple procedure. Used Silica-PEG was stirred with $100 \mathrm{~mL}$ of $5 \%$ hydrochloric acid for $2 \mathrm{~h}$, filtered and dried. The recycled adsorbent can be reused in the same way three times. This means that only a small amount of the adsorbent is used per analysis and the adsorbent has very low consumption and is highly economical.

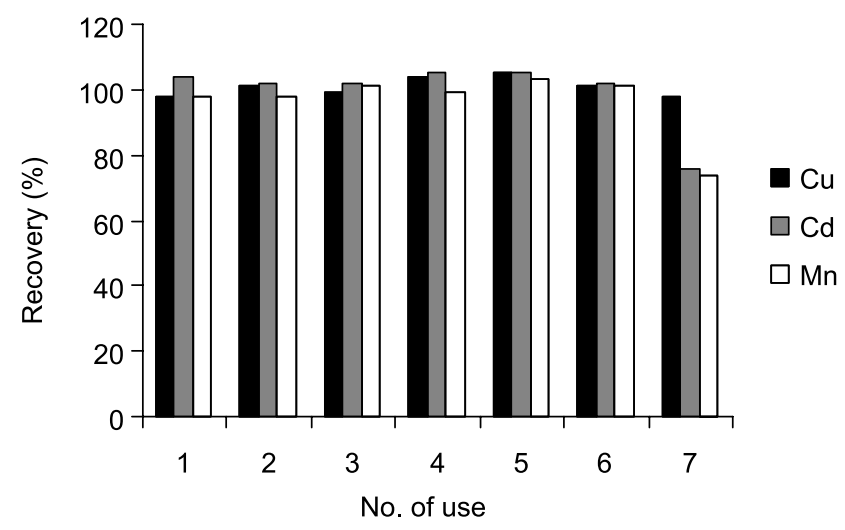

Figure 4. Number of reusing the column. Each number is the average of 3 replicate measurements

\section{Effect of sample solution volume}

In order to achieve a high preconcentration factor, the maximum applicable volume of sample solution must be established. Therefore, the effect of sample solution volume was studied by passing 50-250 $\mathrm{mL}$ solutions containing $10 \mu \mathrm{g}$ of $\mathrm{Cu}$ (II) and $\mathrm{Mn}$ (II) and $5 \mu \mathrm{g}$ of $\mathrm{Cd}(\mathrm{II})$ through the column. The results showed that all the analytes studied could be recovered quantitatively up to sample volumes of $200 \mathrm{~mL}$. At higher sample volumes, the recoveries decreased gradually with increasing volume of sample solution. By analyzing $3 \mathrm{~mL}$ of the final solution after preconcentration of $200 \mathrm{~mL}$ of sample solution, a preconcentration factor of 66.6 can be achieved for all of the analytes.

\section{Analytical performance}

The calibration graph was obtained using the general procedure under optimum conditions. The graphs were linear in the range of 2-140 ng mL $\mathrm{mL}^{-1}$ for $\mathrm{Cu}(\mathrm{II}), 1-40 \mathrm{ng} \mathrm{mL}^{-1}$ for $\mathrm{Cd}(\mathrm{II})$ and $4-100 \mathrm{ng} \mathrm{mL}^{-1}$ for $\mathrm{Mn}(\mathrm{II})$ in the initial solution. The equations of the lines are $\mathrm{A}=$ $0.004 \mathrm{C}+0.008, \mathrm{~A}=0.0126 \mathrm{C}+0.0189$ and $\mathrm{A}=0.0085 \mathrm{C}+0.0189$ for $\mathrm{Cu}(\mathrm{II}), \mathrm{Cd}(\mathrm{II})$ and $\mathrm{Mn}(\mathrm{II})$, respectively, where $\mathrm{A}$ is the absorbance and $\mathrm{C}$ is concentration of metal ions in $\mathrm{ng} \mathrm{mL}^{-1}$. The regression coefficients for the lines are $0.9990,0.9993$ and 0.9980 for $\mathrm{Cu}(\mathrm{II})$, $\mathrm{Cd}(\mathrm{II})$ and $\mathrm{Mn}(\mathrm{II})$, respectively. The limits of detection based on $3 \mathrm{~S}_{\mathrm{b}}$ were $0.66,0.33$ and $1.20 \mathrm{ng} \mathrm{mL}^{-1}$ for $\mathrm{Cu}(\mathrm{II}), \mathrm{Cd}(\mathrm{II})$ and $\mathrm{Mn}(\mathrm{II})$, respectively. The relative standard deviations (RSD) for 10 replicate measurements of $20 \mathrm{ng} \mathrm{mL}^{-1}$ of $\mathrm{Cu}$ (II), $\mathrm{Mn}$ (II) and $10 \mathrm{ng} \mathrm{mL}^{-1}$ of Cd(II) were $4.91,3.79$ and $3.42 \%$, respectively.

\section{Effect of interfering ions}

Interference studies were performed by spiking some ions to the solutions containing $50 \mathrm{ng} \mathrm{mL}^{-1}$ of $\mathrm{Cu}(\mathrm{II}), \mathrm{Mn}$ (II) and $25 \mathrm{ng} \mathrm{mL}^{-1}$ of $\mathrm{Cd}(\mathrm{II})$ and applying the proposed procedure. The recoveries obtained from these solutions were compared with those of standards. Variation of over $\pm 5 \%$ in the recoveries resulting from the presence of interfering ions was taken as interference. The results are shown in Table 1.

\section{Adsorbent capacity}

The adsorption capacity is the maximum metal quantity taken 
Table 1. Effect of various ions on the determination of $50 \mathrm{ng} \mathrm{mL}^{-1}$ of $\mathrm{Cu}$ (II) and $\mathrm{Mn}(\mathrm{II})$ and $25 \mathrm{ng} \mathrm{mL}^{-1}$ of $\mathrm{Cd}(\mathrm{II})$

\begin{tabular}{cc}
\hline Interfering ion & Tolerance ratio \\
\hline $\mathrm{I}^{-}$ & 1000 \\
$\mathrm{Br}^{-}, \mathrm{PO}_{4}^{3-}$ & 500 \\
$\mathrm{NH}_{4}^{+}, \mathrm{SCN}^{-}, \mathrm{NO}_{2}^{-}, \mathrm{Cl}^{-1}, \mathrm{CO}_{3}^{2-}$ & 500 \\
$\mathrm{~F}^{-}, \mathrm{Pb}^{2+}$ & 50 \\
$\mathrm{Ca}^{2+}, \mathrm{Zn}^{2+}, \mathrm{Ni}^{2+}, \mathrm{Cr}^{3+}, \mathrm{Co}^{2+}$ & 10 \\
$\mathrm{Mg}^{2+}, \mathrm{Fe}^{3+}, \mathrm{Fe}^{2+}$ & 1 \\
\hline
\end{tabular}

up by $1 \mathrm{~g}$ of adsorbent. In order to study the adsorptive capacity of Silica-PEG, the batch method was used. $0.5 \mathrm{~g}$ of the adsorbent was added to $100 \mathrm{~mL}$ solution containing $0.5 \mathrm{mg}$ of $\mathrm{Cu}$ (II), and $\mathrm{Mn}$ (II) and $0.1 \mathrm{mg}$ of $\mathrm{Cd}(\mathrm{II})$. After shaking for $24 \mathrm{~h}$, the mixture was filtered and the metal ions remaining in the filtrate were determined by flame atomic absorption spectrometry. The capacity of adsorbent for $\mathrm{Cu}$ (II), $\mathrm{Cd}(\mathrm{II})$ and $\mathrm{Mn}$ (II) was found to be 490, 69 and $102 \mu \mathrm{g} \mathrm{g}^{-1}$ for $\mathrm{Cu}(\mathrm{II})$, $\mathrm{Cd}(\mathrm{II})$ and $\mathrm{Mn}(\mathrm{II})$ ions, respectively.

\section{Application and recovery tests}

In order to check the applicability of the procedure, it was applied for the determination of $\mathrm{Cu}(\mathrm{II}), \mathrm{Cd}(\mathrm{II})$ and $\mathrm{Mn}$ (II) in different samples such as sugar and water samples. In these samples, the analyte concentration was below the detection limit of the method. Thus, different amounts of the investigated metal ions were also spiked to the samples and the resulting solutions were submitted to the preconcentration procedure. The results are given in Table 2 and 3 where it can be seen that good agreement was obtained between the added and found analyte content using the recommended procedure.

Table 2. Determination of $\mathrm{Cu}(\mathrm{II}), \mathrm{Mn}$ (II) and $\mathrm{Cd}(\mathrm{II})$ in sugar

\begin{tabular}{cccc}
\hline Metal ion & Added $\left(\mathrm{ng} \mathrm{mL}^{-1}\right)$ & Found $^{\mathrm{a}}\left(\mathrm{ng} \mathrm{mL}^{-1}\right)$ & Recovery $(\%)$ \\
\hline $\mathrm{Cu}$ & - & $\mathrm{ND}^{\mathrm{b}}$ & - \\
& 10 & $10.5 \pm 0.6$ & 105.0 \\
& 20 & $20.9 \pm 1.2$ & 104.5 \\
$\mathrm{Mn}$ & - & $\mathrm{ND}$ & - \\
& 10 & $10.5 \pm 0.5$ & 105.0 \\
& 20 & $20.3 \pm 0.9$ & 101.1 \\
$\mathrm{Cd}$ & - & $\mathrm{ND}$ & - \\
& 5 & $5.1 \pm 0.2$ & 102.0 \\
& 10 & $9.7 \pm 0.4$ & 97.0 \\
\hline
\end{tabular}

a. $\bar{x} \pm$ ts $/ \sqrt{n}$ at $95 \%$ confidence $(\mathrm{n}=5), \mathrm{b}$. Not detected

Table 3. Determination of $\mathrm{Cu}(\mathrm{II}), \mathrm{Mn}(\mathrm{II})$ and $\mathrm{Cd}(\mathrm{II})$ in surface water

\begin{tabular}{cccc}
\hline Metal ion & Added $\left(\mathrm{ng} \mathrm{mL}^{-1}\right)$ & Found $^{\mathrm{a}}\left(\mathrm{ng} \mathrm{mL}^{-1}\right)$ & Recovery $(\%)$ \\
\hline $\mathrm{Cu}$ & - & $\mathrm{ND}^{\mathrm{b}}$ & - \\
& 50 & $50.7 \pm 2.8$ & 104.5 \\
$\mathrm{Mn}$ & - & $\mathrm{ND}$ & - \\
& 50 & $41.8 \pm 1.5$ & 83.6 \\
$\mathrm{Cd}$ & - & $\mathrm{ND}$ & - \\
& 25 & $23.8 \pm 0.9$ & 95.2 \\
\hline
\end{tabular}

a. $\bar{x} \pm$ ts $/ \sqrt{n}$ at $95 \%$ confidence $(\mathrm{n}=5), \mathrm{b}$. Not detected

\section{CONCLUSION}

The developed SPE procedure allowed the direct determination of $\mathrm{Cu}(\mathrm{II}), \mathrm{Cd}(\mathrm{II})$ and $\mathrm{Mn}$ (II) ions at the level of $\mu \mathrm{g} \mathrm{L}^{-1}$ to be carried out by FAAS. Due to the preconcentration step, it was possible to obtain low limits of detection for these ions. The adsorbent is ecofriendly and a very small amount is consumed per analysis rendering it highly economical. A comparison with some of the different adsorbents available for preconcentration of metal ions is given Table 4 .

Table 4. Comparative data about adsorption of metal ions on different adsorbent materials and determination by FAAS reported in literature

\begin{tabular}{lcccc}
\hline Adsorbent & Elements & PF & DL $\left(\mathrm{ng} \mathrm{mL}^{-1}\right)$ & Ref. \\
\hline $\begin{array}{l}\text { Penicillium digitatum } \\
\text { immobilized on pumice } \\
\text { stone }\end{array}$ & $\mathrm{Cu}(\mathrm{II})$ & 50 & $1.30-5.80$ & 1 \\
& $\mathrm{~Pb}(\mathrm{II})$ & & & \\
$\begin{array}{l}\text { Activated carbon modified } \\
\text { by dithioxamide }\end{array}$ & $\mathrm{Cu}(\mathrm{II})$ & 330 & $0.50-0.80$ & 9 \\
& $\mathrm{Ni}(\mathrm{II})$ & & & \\
& $\mathrm{Co}(\mathrm{II})$ & & & \\
$\begin{array}{l}\text { Saccharomyces } \\
\text { carlsbergensis immobilized } \\
\text { on silica gel }\end{array}$ & $\mathrm{Cu}(\mathrm{II})$ & 50 & $1.14-1.66$ & 10 \\
& $\mathrm{Zn}(\mathrm{II})$ & & & \\
$\begin{array}{l}\text { Chemically modified silica } \\
\text { gel with aminothioamido } \\
\text { anthraquinone }\end{array}$ & $\mathrm{Cd}(\mathrm{II})$ & & & \\
& $\mathrm{Pb}(\mathrm{II})$ & 50 & $0.95-22.50$ & 12 \\
& $\mathrm{Cd}(\mathrm{II})$ & & & \\
& $\mathrm{Cu}(\mathrm{II})$ & & & \\
$\begin{array}{l}\text { Polyethylene glycol silica } \\
\text { gel }\end{array}$ & $\mathrm{Ni}(\mathrm{II})$ & & & This \\
& $\mathrm{Cu}(\mathrm{II})$ & 66.6 & $0.33-1.20$ & \\
& $\mathrm{Cd}(\mathrm{II})$ & & & work \\
\hline
\end{tabular}

As observed, Silica-PEG adsorbent is comparable to, or better than, some of the previously reported adsorbents for metal ions in terms of preconcentration factor and detection limits achieved. Moreover, Silica-PEG is a very promising adsorbent and has potential for use in different applications. The proposed procedure was applied to the determination of $\mathrm{Cu}(\mathrm{II}), \mathrm{Cd}(\mathrm{II})$ and $\mathrm{Mn}$ (II) in surface water and sugar samples with good recoveries for spiked samples.

\section{ACKNOWLEDGEMENT}

The authors wish to thank Shahid Chamran University, Ahvaz, Iran, for financial support of this project (Grant 1390).

\section{REFERENCES}

1. Baytak, S.; Kenduzler, E.; Turker, A. R.; Gok. N.; J. Hazard. Mater. 2008, 153, 975 .

2. Huang, C.; Hu, B.; Spectrochim. Acta, Part B 2008, 63, 437.

3. Oliva, A.; Molinari, A.; Zuniga, F.; Ponce, P.; Mikrochim. Acta 2002, 140, 201.

4. Soylak, M.; Tuzen, M.; J. Hazard. Mater. 2006, B137, 1496.

5. Pourreza, N.; Parham, H.; Mirzavand, P.; J. Chin. Chem. Soc. 2009, 56, 785.

6. Pourreza, N.; Ghanemi, K.; J. Hazard. Mater. 2009, 161, 982.

7. Fathi, M. R.; Pourreza, N.; Purweis, S.; J. Chin. Chem. Soc. 2009, 56, 725.

8. Pourreza, N.; Fathi, M. R.; Ardan, Z.; J. Iran. Chem. Soc. 2010, 7, 965. 
9. Ghaedi, M.; Ahmadi, F.; Soylak, M.; J. Hazard. Mater. 2007, 147, 226.

10. Baytak, S.; Kenduzler, E.; Turker, A. R.; Sep. Sci. Technol. 2006, 41, 3449.

11. Ghaedi, M.; Shokrollahi, A.; Niknam, K.; Soylak, M.; Sep. Sci. Technol. 2009, 44, 773 .

12. Lemos, V. A.; da Franc, R. S.; Moreira, B. O.; Sep. Purif. Technol. 2007, $54,349$.

13. Ghaedi, M.; Shokrollahi, A.; Niknam, K.; Niknam, E.; J. Hazard. Mater. 2009, 168, 1022.

14. Ngeontae, W.; Aeungmaitrepirom, W.; Tuntulani,T.; Talanta 2007, 71,1075 .

15. Moawed, E. A.; El-Shahat, M. F.; React. Funct. Polym. 2006, 66, 720.

16. Gurnani, V.; Singh, A. K.; Venkataramani, B.; Anal. Chim. Acta 2003, $485,221$.
17. Walas, S.; Borowska, E.; Mrowiec, H.; Chem. Anal. 2005, 50, 825.

18. Ramesh, A.; Mohan, K. R.; Seshaiah, K.; Talanta 2002, 57, 243.

19. Puzio, B.; Mikula, B.; Feist, B.; J. Anal. Chem. 2009, 64, 786.

20. Pourreza, N.; Zavvar Mousavi, H.; Talanta 2004, 64, 264.

21. dos Anjos, A. P.; Cornejo-Ponce, L.; Cadore, S.; Baccan, N.; Talanta 2007, 71, 1252.

22. Kiasat, A. R.; Zayadi, M.; Catal. Commun. 2008, 9, 2063.

23. Pourreza, N.; Zolgharnein, J.; Kiasat, A. R.; Dastyar, T.; Talanta 2010, $81,773$.

24. Reymond, J. P.; Kolenda, F.; Powder Technol. 1999, 103, 30.

25. Noah, J. S.; Schwarz, J. A.; Carbon 1990, 28, 675. 